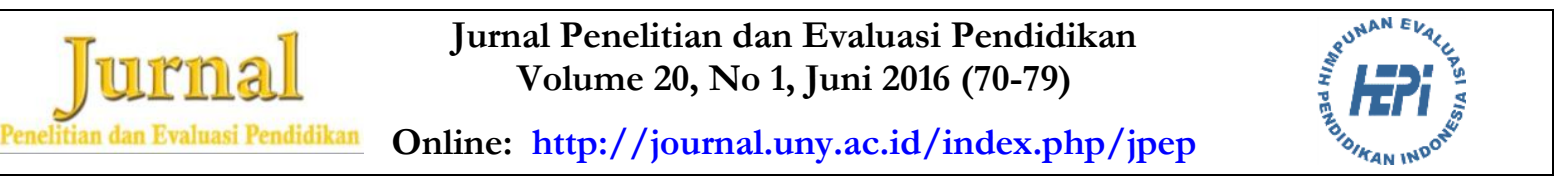

\title{
PEMETAAN MUTU PAUD FULLDAYUNTUK MENINGKATKAN KUALITAS LAYANAN DAN KELEMBAGAAN PROGRAM PAUD
}

\author{
1) Puii Yanti Fauriah, ${ }^{2)}$ Sugito \\ ${ }^{1)}$ pujiyanti@uny.ac.id, ${ }^{2)}$ sugito@uny.ac.id \\ ${ }^{1,2)}$ Fakultas Ilmu Pendidikan Universitas Negeri Yogyakarta
}

\begin{abstract}
Abstrak
Penelitian ini bertujuan untuk: (1) memetakan Program PAUD fullday; (2) menghasilkan rekomendasi penyelenggaraan PAUD fullday. Metode yang digunakan dalam penelitian ini adalah survei. Penentuan lembaga yang dijadikan sampel dilakukan secara acak sejumlah 23 lembaga se-DIY. Adapun hasil penelitiannya: (1) Standar pencapaian perkembangan anak sudah baik tetapi hasil capaian perkembangan baru hasil observasi dan penilaian kegiatan pagi sampai siang dan belum dilakukan terintegrasi dan holistik sepanjang hari; (2) rekomendasi dalam penyelenggaraan Program PAUD fullday adalah: (a) diperlukan kurikulum model pembelajaran yang holistik dalam arti menstimulasi seluruh aspek perkembangan anak dari pagi sampai sore; (b) diperlukan model penilaian yang integratif dari pagi sampai sore dari keseluruhan aktivitas anak, dan (c) pentingnya pemberdayaan orang tua dalam pembelajaran fullday dan lembaga telah melakukan pemberdayaan dengan baik.
\end{abstract}

Kata kunci: PAUD fullday, kualitas layanan dan kelembagaan

\section{THE QUALITY MAPPING OF FULL DAY ECD FOR IMPROVING THE QUALITY OF SERVICE AND INSTITUTIONAL PROGRAMS ECD}

\author{
1) Puji Yanti Fauriah, ${ }^{2}$ Sugito \\ ${ }^{1)}$ pujiyanti@uny.ac.id, ${ }^{2)}$ sugito@uny.ac.id \\ ${ }^{1,2)}$ Fakultas Ilmu Pendidikan Universitas Negeri Yogyakarta
}

\begin{abstract}
This research aims to: (1) mapping the full day early childhood program; (2) Recommendation implementation of full day early childhood education. The method used in this research is the survey. Determination institution randomized sample number 23 taken from the early childhood institutions throughout the District. The description of the implementation of full day early childhood are: 1 Achievement standard child development has been good but the results of the achievements of the new developments on the observation and assessment of activities in the morning until noon, has not carried out an integrated and holistic throughout the day. recommendations for the implementation of full day early childhood program; (a) required a holistic learning model in the sense of stimulating all aspects of child development from morning till evening; (b) assessment of the achievement of the child's development has not been documented in a neat necessitating a thorough assessment model of the overall activity of the child; (c) the importance of empowering parents in a full day of learning, and institutions have to empower parents with the good
\end{abstract}

Keywords: full day early childhood, quality of service and institutional 



\section{Pendahuluan}

Pembentukan kualitas sumber daya manusia ditentukan oleh tiga lingkungan, yaitu sekolah, keluarga dan masyarakat. Dewantara (1962, p.386) menyebutnya dengan tiga alam pendidikan. Berbagai penelitian ilmiah tentang pentingnya pendidikan keluarga menyebutkan bahwa keluarga sebagai pendidikan utama dan pertama bagi anak.

Perubahan sosial yang terjadi pada bentuk keluarga dari keluarga besar (extended family) menjadi keluarga inti (nuclear family) menyebabkan adanya perubahan pola asuh yang sangat bergantung pada pasangan suami istri. Hal ini senada dengan yang dikemukakan oleh Faturochman (2001, p. 2) yang diambil dari Ardiner \& Gardiner, 1988 selama beberapa dekade terakhir, keluarga mengalami perubahan bentuk dari ukuran keluarga besar menjadi lebih kecil. Perubahan ini mempengaruhi aspek-aspek yang lainnya. Perubahan pertama adalah adalah jumlah keluarga mengecil dari keluarga luas menjadi keluarga inti. Kedua selama masa transisi ini peran keluarga mengalami perubahan dari peran sosial emosional keluarga ke peran ekonomis. Fenomena peningkatan suami istri bekerja banyak mengurangi waktu keluarga sehingga anak lebih banyak berinteraksi dan dipengaruhi oleh lingkungan sekolah.

Peningkatan peran istri bekerja dari tahun ke tahun mengalami peningkatan, hal ini didukung oleh adanya revolusi industri yang banyak memberikan kesempatan perempuan untuk bekerja. Hasil penelitian di Amerika menunjukkan selama beberapa dekade perempuan bekerja mengalami peningkatan. Penelitian dilakukan pada keluarga yang memiliki anak usia di bawah 18 tahun. Pada tahun 1940 perempuan bekerja hanya berjumlah 8,6\%. Tahun 1946 naik menjadi 18,2\%, tahun 1956 naik lagi menjadi 27,5\%, 1966 mengalami kenaikan 35.5\%, 1976 naik menjadi 48,8\%, 1986 naik lebih besar menjadi 62,5\%, dan pada tahun 1996 mencapai angka $70 \%$. Perubahan dan peningkatan data ibu bekerja juga sangat berpengaruh pada status keluarga, status perempuan, sikap orang tua dan perspektif gender anak (persepsi anak tergantung pada jenis kelamin dan efek besar terjadi pada keluarga menengah ke bawah (Hoffman, p.2).

Hoffman menemukan tentang perbedaan dampak ibu bekerja dan ibu tidak bekerja pada anak yaitu: (1) Anak perempuan yang memiliki Ibu bekerja ditemukan bahwa anak perempuan tersebut memiliki prestasi akademik yang lebih tinggi, karir yang lebih sukses, memiliki banyak pilihan karir nontradisional dan memiliki komitmen pekerjaan; (2) pada anak yang berasal dari keluarga miskin baik dari orang tua lengkap maupun single parent, ditemukan bahwa anak yang memiliki ibu bekerja memiliki skor kognitif yang lebih tinggi serta indikator sosial emosional yang lebih baik; (3) penemuan penelitian pada akhir-akhir tahun ditemukakan bahwa pada keluarga menengah yang memiliki anak laki-laki dan ibu bekerja, anak laki-laki memiliki performance yang lebih rendah dibandingkan dengan anak yang ibunya tidak bekerja.

Hasil penelitian Hoffman (2008, p.3) menyebutkan bahwa ibu bekerja yang menikmati pekerjaannya memiliki interaksi positif dengan anaknya, lebih simpatik dan lebih sedikit memperlihatkan kemarahannya dalam situasi mendisiplinkan anak. Hal ini terjadi karena ibu bekerja merasa bersalah ketika meninggalkan anak dan berusaha menjadi ibu yang baik secara berlebihan. Anak merasakan pola asuh yang terlalu melindungi. Di sisi lain ibu yang tidak menikmati pekerjaannya cenderung menggunakan metode yang keras dalam mendidik anak, memperlihatkan sedikit kasih sayang dibanding dengan ibu-ibu yang dapat menikmati pekerjaannya.

Penelitian lain terkait dengan pekerjaan dan pendidikan orang tua adalah hasil penelitian dari Charlene yang menemukan bahwa terdapat pengaruh signifikan selain sekolah yaitu anak yang memiliki latar belakang pendidikan tinggi berpengaruh terhadap kemampuan membaca anak. Hal ini dipengaruhi oleh kebiasaan oran tua dalam hal membaca dan dilihat oleh anaknya. (Hildebrand). 
Tahun 1999-1998 di Amerika mulai berkembang fullday school kindergarten, bahkan 61\% lembaga Kindergarten sudah menyediakan layanan fullday. (NCE, 2014, p.15). Hal ini berbeda dengan di Indonesia karena konsep PAUD Fullday baru berkembang baru tahun 2010-an, bahkan sampai saat ini penyelenggaraan PAUD Fullday belum dapat diidentifikasi dan didata oleh pemerintah untuk mengetahui jumlah pasti lembaga yang menyelenggarakan PAUD Fullday.

Fenomena ibu bekerja juga terjadi di Indonesia, menurut data statistik Angka partisipasi pendidikan di Indonesia berdasarkan jenis kelamin pada tingkat SMU pada tahun 2011 seimbang antara laki-laki dan perempuan. Perempuan 48,31 \% dan lakilaki 47,64\%. Hal ini tentu saja akan berdampak pada kesempatan pekerjaan yang lebih besar bagi perempuan.

Adanya peningkatan perempuan bekerja dan perubahan bentuk keluarga yang lebih kecil atau menjadi keluarga inti menyebabkan keluarga membutuhkan mitra dalam pengasuhan anak. Saat ini terutama di kota-kota besar terjadi peningkatan jumlah lembaga baby day care dan sekolah-sekolah fullday. Menurut data statistik jumlah lembaga PAUD saat ini mencapai ribuan lembaga PAUD. Di Daerah Istimewa Yogyakarta (DIY) lembaga yang memfasilitasi program full day dan TPA semakin memiliki beragam jenis dan bentuk layanan. Mulai dari TK Fullday, TPA, SD kelas rendah fullday yang semuanya memfasilitasi bagi keluarga kecil yang pasangannya bekerja. Hal ini tidak hanya terjadi di Indonesia bahkan studi di Rhode Island pada tahun 2004-2005 menunjukkan bahwa 100\% anak-anak mengikuti fullday Kindergarten Program.

Program Fullday Kindergarten adalah program pendidikan yang memberikan layanan minimum 6 jam dalam sehari yang dimulai pada pukul 08.00 sampai pukul 15.00. Hasil riset menemukan bahwa anakanak yang mengikuti fullday kindergarten memiliki kesiapan dalam mengikuti sekolah dasar, dan memiliki kemampuan membaca jika dibandingkan dengan anak-anak yang mengikuti program balf day. Anak-anak di fullday memiliki kelebihan dan kesiapan belajar karena menurut hasil penelitian Guru memiliki lebih banyak waktu untuk dapat mengidentifikasi gaya belajar anak, kebutuhan anak serta permasalahan yang dihadaip anak. Dari perspektif anak-anak, mereka lebih banyak memiliki pilihan untuk melakukan berbagai aktivitas, pilihan belajar, dan memperdalam materi karena waktu yang lebih banyak.

Indonesia sebagai negara berkembang masih memiliki keterbatasan tentang penelitian yang berkenaan dengan fullday program baik efektivitas, pengaruh terhadap anak serta model-model pembelajaran yang dilakukan. Penelitian ini akan memetakan tentang program-program full day yang telah berjalan kemudian mengembangkan berbagai macam model layanan pembelajaran PAUD Fullday.

\section{Metode}

Penelitian ini menggunakan pendekatan survei. Lembaga penyelenggara PAUD Fullday dari lima Kabupaten se DIY dipetakan dengan menggunakan instrumen kuesioner, wawancara melalui FGD dan studi dokumentasi.

Subjek dalam penelitian ini adalah lembaga-lembaga PAUD Fullday yang sudah memberikan layanan fullday pada masyarakat. Penentuan sampling dengan metode purposive sampling yaitu memilih lembagalembaga yang memiliki fullday. Dalam mengukur ketercapaian standar mutu, kuesioner menggunakan skala satu sampai dengan empat. Komponen yang dikembangkan dalam kuesioner adalah standar pencapaian perkembangan anak TK, isi proses dan penilaian dan standar pengelolaan dan pembiayaan.

\section{Hasil Penelitian dan Pembahasan}

Keluarga merupakan pendidikan utama dan pertama bagi anak. Akan tetapi dengan adanya perubahan sosial yang terjadi pada bentuk keluarga dari keluarga besar (extended family) menjadi keluarga inti (nuclear family) menyebabkan adanya perubahan pola asuh yang sangat bergantung pada pasangan 
suami istri. Hal ini senada dengan yang dikemukakan oleh Faturochman (2001, p.2) yang diambil dari ey ardiner \& Gardiner, 1988 selama beberapa dekade terakhir, keluarga mengalami perubahan bentuk dari ukuran keluarga besar menjadi lebih kecil.

Peningkatan wanita bekerja di Indonesia terjadi karena dua faktor yaitu adanya penawaran dan permintaan. Penawaran terjadi karena adanya perbaikan pendidikan di kalangan perempuan, serta adanya perubahan dan pergesaran persepsi masyarakat yang memaklumi wanita bekerja. Penawaran terjadi karena semakin terbukanya lapangan pekerjaan bagi pekerja wanita dan penyebab utama adalah semakin tingginya biaya hidup yang menyebabkan pasangan suami istri harus bekerja, fenomena ini dapat dilihat terutama di kota-kota besar (Tjiptoheriyanto dalam Tjaja, 2000).

Peningkatan wanita bekerjapada kalangan TKI menimbulkan konsekwensi dimana pengasuhan anak diserahkan pada kerabat atau suami (Winda Yunitasari). Sedangkan pada wanita terdidik yang bekerja di sektor industri lebih memilih layanan pengasuhan baby sitter atau PAUD fullday. PAUD fullday membutuhkan kemampuan finansial yang relatif lebih besar. Hal ini sesuai dengan hasil penelitian di Amerika bahwa PAUD fullday lebih mahal jika dibandingkan dengan PAUD half day atau kelas reguler. Fullday lebih mahal karena pembiayaan untuk anak termasuk dalam biaya makan, pengasuhan yang lebih panjang menyebabkan jam kerja guru dan pengasuh lebih panjang, kebutuhan ruangan yang lebih luas (Plucker et all, 2004).

Menurut data statistik nasional jumlah Guru Taman kanak-kanak berjumlah 7633 orang, dengan rasio siswa dan guru di DIY adalah satu berbanding 10 siswa. Semakin kecil usia anak, maka rasio anak dan guru semakin kecil. Jumlah pendidik dan pegasuh di PAUD fullday berbanding dengan jumlah anak, dan DIY termasuk dalam kategori ideal. Sehingga biaya PAUD fullday lebih mahal jika dibandingan dengan layanan PAUD reguler.
Salah satu kendala yang dihadapi dalam penelitian adalah sampai saat ini tidak ada data yang menyajikan tentang jumlah PAUD fullday, yang tersedia data jumlah lembaga Taman kanak-kanak, kelompok bermain, Taman penitipan anak dan SPS PAUD. (Statistik PAUD 2014).

Hal ini berbeda dengan hasil temuan Plucker tentang fullday di Indiana, dimana lembaga PAUD fullday sudah memiliki data sejak tahun1978, kemudian pada tahun 2004 mulai menganalisis tentang dampak fullday pada kemampuan akademik anak, motivasi anak, kemampuan membaca, kemampuan matematik dimana anak-anak fullday memiliki kemampuan lebih baik jika dibandingkan dengan anak-anak halfday. Tetapi disisi finansial fullday memiliki biaya yang lebih tinggi (Plucker 2004, p.29).

Data UNESCO tahun 2005 menyebutkan bahwa lembaga PAUD lebih terkonsentrasi didaerah perkotaan, terutama pada layanan kelompok bermain. Sedangkan hasil survey UNESCO pada 200 layanan PAUD terungkap bahwa layanan pendidikan anak usia dini 99\% dikelola oleh swasta dan sisanya adalah negeri atau pemerintah. Hal ini berbeda dengan kondisi Malaysia yang jumlah lembaga PAUD anatara pemerintah dan swasta perbandingannya $41 \%$ swasta dan lebih banyak pemerintah. (Laporan tahunan UNESCO 2005). Halini semakin menjelaskan bahwa investasi atau perhatian pemerintah terhadap dunia PAUD masih sangat minim. Sehingga jika masyarakat ingin mendapatkan layanan PAUD berkualitas masyarakat harus membayar lebih mahal.

Program fullday Kindergarten adalah program pendidikan yang memberikan layanan minimum 6 jam dalam sehari yang dimulai pada pukul 08.00 sampai pukul 15.00. Hasil riset menemukan bahwa anakanak yang mengikuti full day kindergarten memiliki kesiapan dalam mengikuti sekolah dasar, dan memiliki kemampuan membaca jika dibandingkan dengan anak-anak yang mengikuti program half day. Anak-anak di full day memiliki kelebihan dan kesiapan belajar karena menurut hasil penelitian, 
Guru memiliki lebih banyak waktu untuk dapat mengidentifikasi gaya belajar anak, kebutuhan anak serta permasalahan yang dihadapi anak. Sedangkan dari perspektif anak-anak, mereka lebih banyak memiliki pilihan untuk melakukan berbagai aktivitas, pilihan belajar, dan memperdalam materi karena waktu yang lebih banyak.

Indonesia sebagai Negara berkembang masih memiliki keterbatasan tentang penelitian yang berkenaan dengan fullday program baik efektivitas, pengaruh terhadap anak serta model-model pembelajaran yang dilakukan. Temuan Penelitian ini memetakan tentang program-program fullday yang telah dilaksanakan, kemudian mengembangkan berbagai macam pembelajaran yang dilakukan. Lembaga-lembaga PAUD Kelompok Bermain (KB), Taman Penitipan Anak (TPA) dan satuan PAUD Sejenis (SPS) berada di bawah koordinasi Himpaunan Pendidik PAUD (HIMPAUDI DIY). HIMPAUDI DIY memiliki visi Terwujudnya pendidik dan tenaga kependidikan anak usia dini Indonesia yang tangguh, profesional dan berakhlak mulia pada tahun 2015, Adapun misi HIMPAUDI: (1) menghimpun pendidik dan tenaga kependidikan anak usia dini indonesia untuk mencerdaskan bangsa; (2) meningkatkan profesionalisme pendidik dan tenaga kependidikan anak usia dini Indonesia; (3) meningkatkan kesejahteraan pendidik dan tenaga kependidikan anak usia dini Indonesia; (4) menjalin kemitraan dengan berbagai pihak dalam meningkatkan daya juang HIMPAUDI; Untuk jumlah lembaga PAUD di Indonesia tercatat 186.627 lembaga. ().

Menurut data PAUDNI jumlah peserta didik berdasarkan jenis satuan di DIY terbagi dalam empat jenis layanan yaitu TK, KB, TPA dan SPS. Adapun jumlah peerta didik adalah 132.951 yang terbagi atas 67.515 anak laki-laki dan 65.436 anak perempuan. Sedangkan jumlah anak PAUD di DIY 214.785 dan anak yang terlayani di lembaga PAUD sejumlah 210.352 artinya angka partisipasi kasar DIY sebanyak 97\%. (Kemendikbud Final APK APM gabungan 2013). APK DIY termasuk APK tertinggi di
Indonesia. Walaupun terdapat perbedaan jumlah peserta didik antara data dari PAUDNI dan data dari Kemendikbud namun memiliki persamaan bahwa jumlah anak di DIY hampir seluruh anak sudah terlayani dari pelbagai satuan pendidikan PAUD yang ada baik TK, KB, TPA maupun SPS.

Adapun secara lebih rinci jumlah seluruh lembaga PAUD di DIY terdapat 5.575 lembaga PAUD yang terdiri dari 80 lembaga negeri dan 5.364 lembaga PAUD swasta. Sedangkan data lembaga PAUD berdasarkan jenis satuan terbagi atas 2042 TK, 1612 KB, 231 TPA dan 1688 SPS. Sehingga jumlah total keseluruhan lembaga adalah 5.575 .

Dalam penelitian ini lembaga yang diteliti fokus pada lembaga yang memberikan layanan PAUD fullday. Kesulitan tim peneliti adalah data PAUD fullday tidak muncul dalam profil propinsi, sehingga pengambilan sampel dilakukan dengan purposive sampling. Jadi lembaga-lembaga PAUD yang diidentifikasi memberikan layanan PAUD fullday baik dari satuan TK, KB dan TPA diambil untuk dijadikan sampel. Lembaga yang diambil adalah 25 lembaga penyelenggara PAUD fullday berikut data pemetaan hasil penelitian.

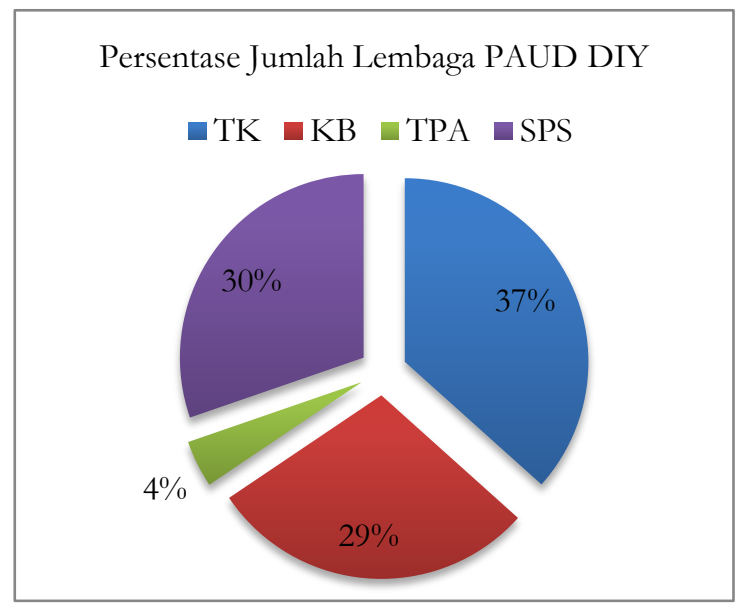

Gambar 1. Persentase Jumlah Lembaga PAUD DIY

Pendidik dan Tenaga Kependidikan

Berdasarkan hasil penelitian ditemukan kualifikasi dan kompetensi pendidik 
terutama kepala lembaga PAUD. dilihat dari aspek pengalaman yang menjadi kepala lembaga PAUD 100\% memiliki pengalaman lebih dari lima tahun, sedangkan dari sisi kualifikasi pendidikan $57 \%$ berpendidikan S1 dan $43 \%$ berpendidikan D3. Dari aspek kepangkatan $14 \%$ responden adalah PNS golongan III dan $43 \%$ nonPNS yang diangkat yayasan dan $43 \%$ lainnya kepala lembaga yang yayasannya tidak memiliki sistem kepangkatan seperti disajikan pada Gambar 2.

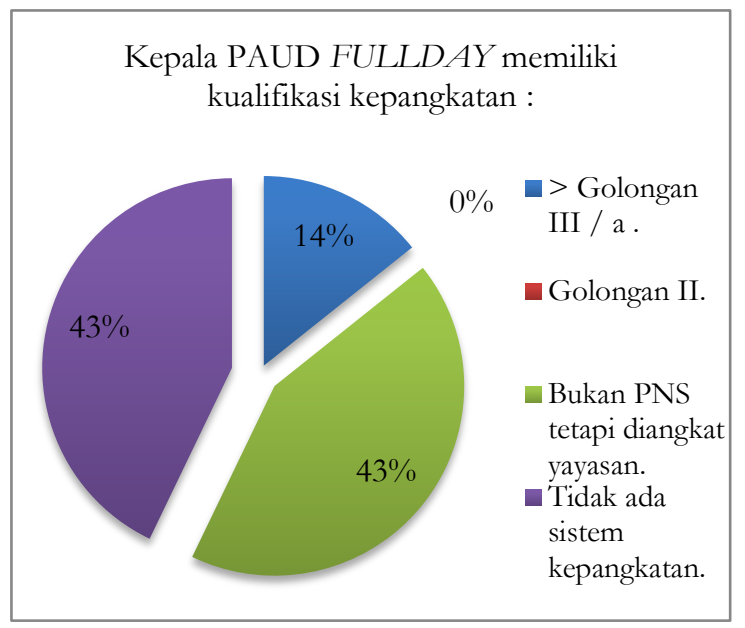

Gambar 2. Kualifikasi Kepangkatan Kepala Lembaga PAUD
Persepsi guru dan tenaga kependidikan dilihat dari beberapa kompetensi kepala lembaga yang indikatornya terdiri dari: (1) menyusun perencanaan PAUD fullday untuk berbagai tingkatan perencanaan kepala lembaga memiliki persepsi yang sangat baik dengan pemberian skor nilai di atas 85 ; (2) mengembangkan organisasi PAUD fullday sesuai dengan kebutuhan mendapatkan persepsi yang cukup dengan skor 65, artinya kemampuan kepala lembaga masih perlu dikembangkan jika dikaitkan dengan pengembangan program untuk memenuhi kebutuhan dari masyarakat; (3) indikator memimpin PAUD fullday dalam rangka pendayagunaan sumber daya sekolah/madrasah secara optimal mendapatkan persepsi sangat baik; indikator menciptakan budaya dan iklim sekolah/madrasah yang kondusif dan inovatif bagi pembelajaran peserta didik; memanfaatkan kemajuan teknologi informasi bagi peningkatan pembelajaran dan manajemen PAUD fullday; dan melakukan monitoring, evaluasi, dan pelaporan pelaksanaan program kegiatan PAUD fullday dengan prosedur yang tepat, serta merencanakan tindak lanjutnya. Untuk lebih detail dapat terlihat pada Gambar 3.

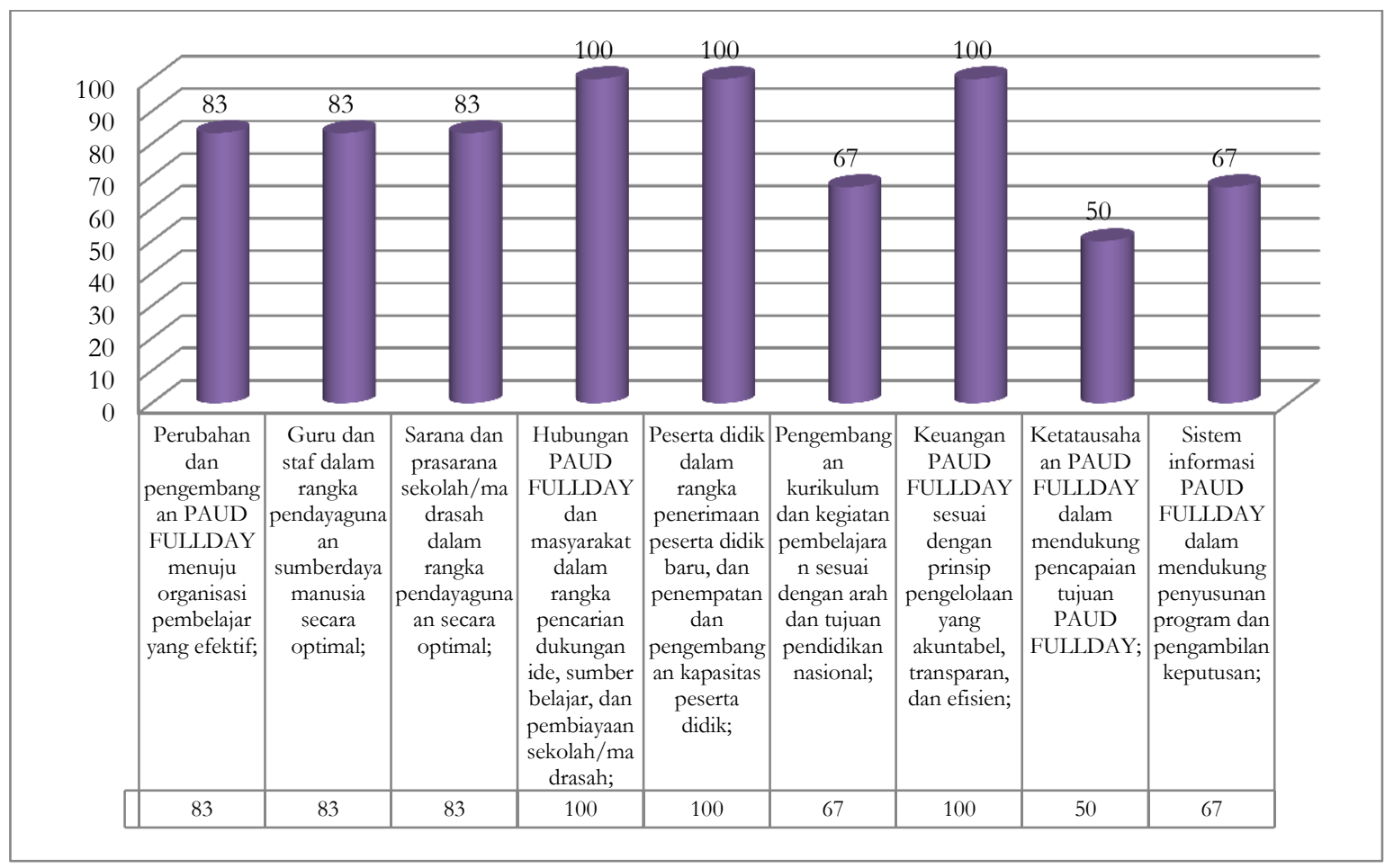

Gambar 3. Kompetensi Manajerial Kepala PAUD Fullday 


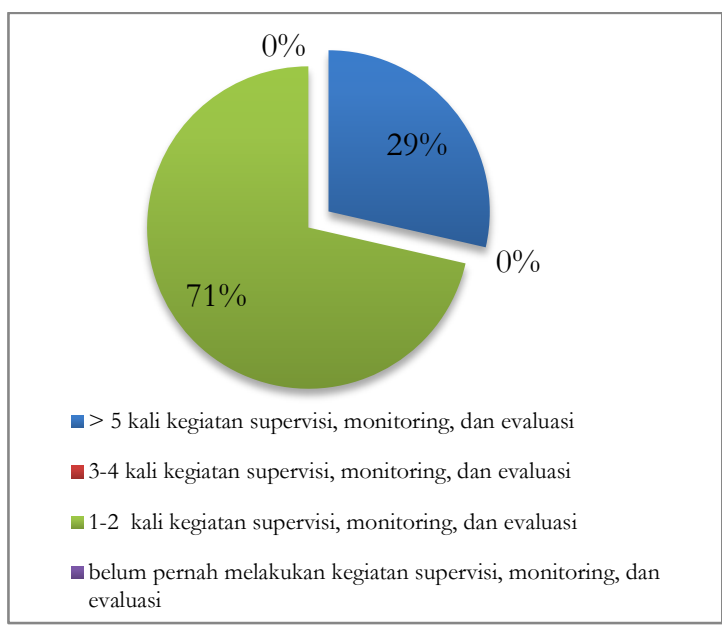

Gambar 4. Intensitas Kepala PAUD Fullday melakukan Supervisi, monitoring, dan Evaluasi dalam setahun

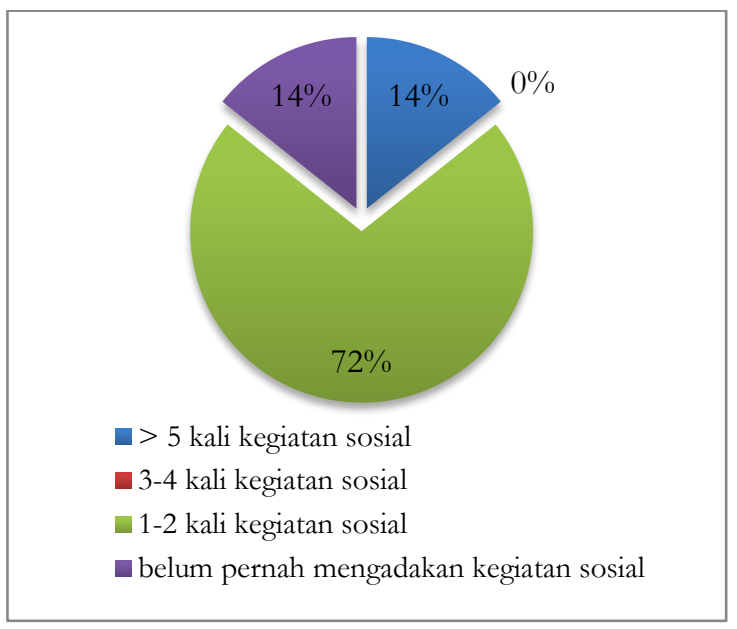

Gambar 5. Kegiatan Sosial yang Diselenggarakan PAUD Fullday

Intensitas Kepala PAUD fullday melakukan supervisi, monitoring, dan evaluasi dalam waktu 1 tahun: 29\% responden menjawab bahwa kepala lembaga melakukan $>5$ kali kegiatan supervisi, monitoring, dan evaluasi; 3-4 kali kegiatan supervisi, monitoring, dan evaluasi; dan 72\% 1-2 kali kegiatan supervisi, monitoring, dan evaluasi; $0 \%$ lembaga belum pernah melakukan kegiatan supervisi, monitoring, dan evaluasi. Artinya proses monitoring dan supervisi kepala lembaga pada umumnya sudah dilakukan tetapi dalam intensitas yang berbeda tiap tahunnya. Intensitas Kepala PAUD melakukan supervisi, monitoring, dan evaluasi dalam waktu satu tahun disajikan pada Gambar 4.

Kepala PAUD fullday mempunyai kompetensi sosial, meliputi: bekerja sama dengan pihak lain untuk kepentingan PAUD fullday; berpartisipasi dalam kegiatan sosial kemasyarakatan; dan memiliki kepekaan sosial terhadap orang atau kelompok lain yang ditunjukkan dengan $72 \%$ lembaga melakukan kegiatan sosial 1-2 kali dalam setahun, 14\% lebih dari lima kegiatan sosial dan 14\% melakukan kegiatan sosial 3-4 kegiatan sosial dalam setahun yang disajikan pada Gambar 5.

Peta Standar Isi, Proses dan Penilaian

Adapun struktur Program PAUD terdiri dari aspek. Pertama, aspek pengembangan anak. 100\% lembaga telah mengembangkan lima aspek yang terdiri dari aspek nilai dan moral, sosial emosional, fisik motorik dan bahasa. Kedua, waktu pelayanan. $72 \%$ lembaga memberikan layanan lebih dari 120 menit per minggu, karena lembaga yang di undang adalah lembaga penyelenggaran PAUD fullday. Aspek-aspek tersebut disajikan Gambar 6.

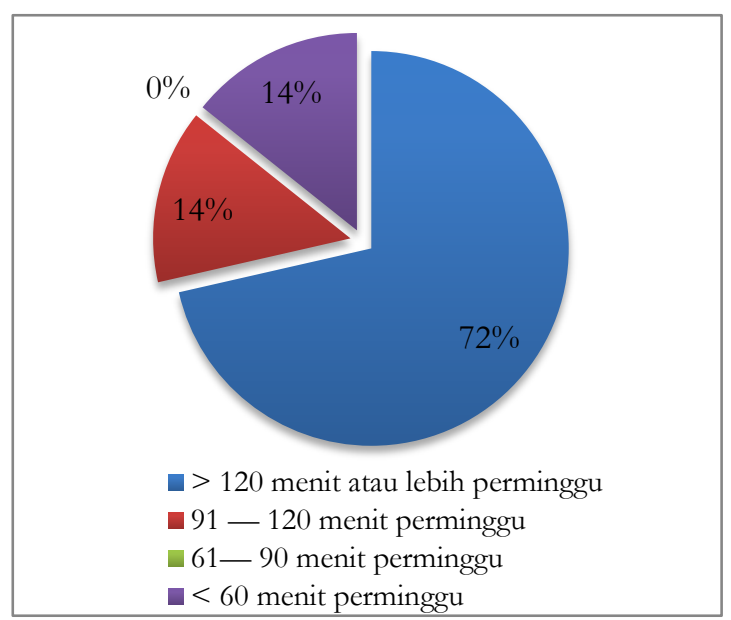

Gambar 6. Waktu Pelayanan PAUD Fullday

Struktur program kegiatan di PAUD fullday mencakup bidang pengembangan pembentukan perilaku dan bidang pengembangan kemampuan dasar melalui pembiasaan yang dimasukan dalam program tahunan, semester dan bulanan. Sedangkan 
untuk ruang lingkup pengembangan anak $100 \%$ lembaga telah mengembangkan aspek nilai, fisik, bahasa, sosial dan emosional.

Pengelompokkan usia anak ditentukan oleh jenis layanan pendidikan yang diberikan. Pengelompookan usia adalah 0-3 bulan, 4-9 bulan, 10-16 bulan, 16-24 bulan, $>24$ bulan. Untuk TPA memberikan layanan 0-16 bulan, sedangkan untuk $\mathrm{KB}$ dan TPA memberikan layanan lebih dari 24 bulan. Untuk responden lembaga yang diteliti pada umumnya sudah memiliki tiga layanan PAUD yang terintegrasi $82 \%$ yaitu memiliki TPA, KB dan TK sedangkan sisanya fokus pada salah satu layanan yaitu TPA dan KB.

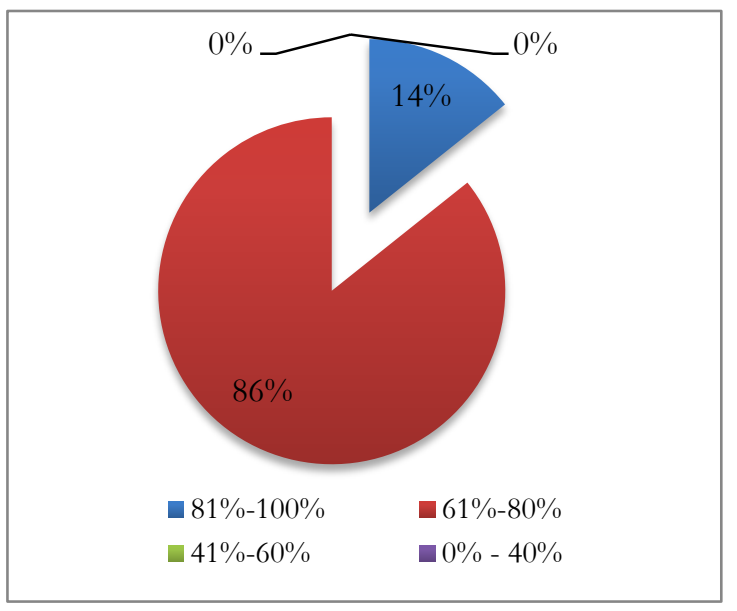

Gambar 7. Jumlah Lembaga yang Sudah Mengembangkan Pembelajaran Tematik

Perbandingan pengasuh atau pendidik di PAUD fullday usia 0- kurang dari satu tahun adalah adalah 57\% 1:4; 14\% 1:6 dan 1:7 14\%. Untuk usia $0-<1$ tahun memiliki rasio pengasuh/pendamping dengan peserta didik bersifat fleksibel sesuai jenis layanan program, dengan jumlah minimal pendidik/ pendamping 1 orang. Lebih jelas dapat dilihat dalam bagan 7. Untuk usia 1-2 tahun rasio pegasuh dan anak $72 \%$ responden memiliki perbandingan 1: 6 atau lebih kecil, dan 28\% memiliki rasio lebih besar yaitu satu pengasuh dengan lebih dari enam anak. Untuk kelompok usia 2-3 tahun $87 \%$ responden memiliki perbandingan pengasuh 1 berbanding 8 anak dan 13\% lainnya memiliki perbandingan yang lebih tinggi yaitu satu pengasuh dengan lebih dari 8 anak.
Setiap lembaga telah memiliki kalender pendidikan dengan komponen pengaturan kegiatan waktu pembelajaran selama satu tahun, hari libur dan hari penting pendidikan.

Proses pembelajaran dimulai dengan pembuatan rencana kegiatan harian yang dibuat, untuk RKH usia 0-2 tahun sebanyak 71\% lembaga Memperhatikan karakteristik anak ketika membuat RKH dan memperhatikan kebiasaan setiap anak; RKH hanya dibuat sampai jam pembelajaran yang sangat variatif mulai dari jam delapan pagi sampai dengan jam 10 atau jam 13.00. Setelah kegiatan pembelajaran di kelas selesai maka aktivitas after school lebih pada aktivitas bebas untuk anak, dari 25 lembaga hanya 25\% lembaga yang telah memadukan aktivitas pembelajaran inti formal dengan kegiatan after school sampai dengan penjemputan. Sisanya 14\% lembaga Tidak membuat RKH dan menyamakan seluruh kelompok anak dan lebih banyak pada pengasuhan. Sedangkan untuk kelompok satuan kelompok bermain dan TK 100\% para pendidik telah membuat RKH dan RKM setiap hari.

Lembaga PAUD fullday menerapkan prinsip pembelajaran, meliputi: $71 \%$ lembaga memperhatikan tingkat perkembangan, kebutuhan, minat dan karakteristik anak artinya ketika lembaga menyusun rencana pembelajaran pembelajaran disesuaikan dengan tingkat perkembangan, kebutuhan minat dan karakteristik anak, tetapi dari hasil wawancara didapatkan informasi dan data tambahan bahwa pembelajaran yang diobservasi oleh pendidik atau guru terbatas pada jam pembelajaran inti di kelas, setelah selesai kegiatan inti kegiatan tambahan lebih banyak pada proses pengasuhan dan diserahkan pada pengasuh dengan kegiatan bebas. Terkait dengan integrasi kesehatan gizi, pendidikan dan pengasuhan jumlah lembaga yang memadukan dengan aspek gizi dan kesehatan anak baru sebanyak $43 \%$ lembaga, artinya kesehatan fisik anak sudah dilakukan dan difasilitasi tetapi tidak dimasukkan dalam lingkup pembelajaran secara interaktif. Cek kesehatan dilakukan secara berkala oleh semua lembaga tetapi hasil 
tes kesehatan atau gizi jarang digunakan oleh guru sebagai bahan pembelajaran di kelas. Untuk metode pembelajaran 86\% lembaga memakai Pembelajaran melalui metode bermain dan dilakukan secara bertahap, berkesinambungan, dan bersifat pembiasaan. Dari hasil wawancara diketahui bahwa lembaga-lembaga yang telah memberikan layanan PAUD fullday menggunakan pelbagai sumber pembelajaran dan kegiatan outing class atau field trip. Dari hasil penelitian ini diharapkan sesuai dengan teori bermain Hurlock bahwa outing class dan bermain menjadi metode pembelajaran yang sangat menarik. Karena bermain menurut Hurloc adalah proses yang membuat ana tahu tentang dunia-meniru, mengeksplorasi, menguji dan membangun (Hurlock 1999).

Dalam pembuatan RKH komponen yang menjadi pertimbangan dalam membuat rencana pembelajaran adalah metode permainan, alat bermain, sumber pembelajaran dan teknik penilaian serta alat penilaian. Alat permainan edukatif yang digunakan diantaranya seperti playdogh, puzzle, boneka, APE dalam, APE luar, menara donat dan balok. Lingkungan sekitar juga sering dimanfaatkan untuk pembelajaran terutama ketika pembelajaran inti .

Terkait dengan keterlibatan orang tua, dari hasil penelusuran dokumentasi 100\% orang tua anak yang mengikuti PAUD fullday ibu dan bapaknya bekerja dan orang tua yang sedang tugas belajar. Untuk komunikasi dengan orang tua dari hasil wawancara diketahui bahwa komunikasi dilakukan melalui media buku penghubung, sehingga komunikasi dilakukan dengan intensitas harian, bulanan dan tengah semester dan tahunan. Adapun materi yang dikomunikasikan adalah perkembangan anak terkait dengan aspek moral, nilai, sosial, emosional, bahasa dan motorik anak. Adapun intensitas komunikasi 50\% lembaga melakukan komunikasi lebih dari empat kali komunikasi dengan orang tua selama satu semester, 33\% lembaga berkomunikasi sebanyak dua kali, dan $17 \%$ sisanya berkomunikasi secara formal 3 kali dalam satu semester.
Metode penilaian dilakukan melalui catatan anekdot sebanyak $71 \%$ lembaga, $57 \%$ lembaga membuat catatan pengamatan, dan 43\% melakukan ceklis, dan 60\% melakukan penilaian melalui portofolio. Penilaian portofolio dilakukan dengan menganalisis hasil kerja anak, pada umumnya pendidik hanya mengumpulkan hasil karya anak tanpa melakukan analisa atau pengamatan terhadap hasil karya anak, tentang pencapaian yang telah dimiliki oleh anak.

Sedangkan materi yang dikomunikasikan orang tua tentang hasil penilaian yang telah dianalisa oleh pendidik sebanyak $72 \%$ lembaga hanya dilakukan kurang dari dua kali selama satu semester, artinya komunikasi awal yang ditanyakan peneliti terkait dengan intensitas komunikasi lebih banyak dilakukan terbatas pada aktivitas di kelas namun untuk hasil analisa perkembangan anak masih jarang dilakukan. Disamping itu masih ada 14\% lembaga yang melakukan komunikasi dengan orang tua tentang analisa hasil penilaian terkait tumbuh kembang anak dilakukan lebih dari empat kali dalam satu semester, setelah di teliti lebih dalam lembaga tersebut memiliki wahana komunikasi melalui program parenting yang secara berkala telah dilakukan, tidak hanya pada pendidikan anak tetapi dimanfaatkan untuk laporan perkembangan anak bulanan.

Selain dilaporkan kepada orang tua lembaga PAUD memanfaatkan hasil penilaian untuk perbaikan program, perbaikan pembelajaran, peningkatan kompetensi pedagogik pendidik, penyediaan sarana pembelajaran dan kebersihan serta sarana prasarana bagi anak yang berkebutuhan khusus.

\section{Simpulan dan Saran}

Simpulan

Berdasarkan hasil temuan pemetaan yang dilihat dari empat standar sesuai dengan permen No 58 tahun 2009 .Adapun hasil penelitiannya adalah sebagai berikut. Pertama, capaian standar standar pencapaian perkembangan sudah baik. Kualifikasi kepala sekolah sudah baik rata-rata memiliki kualifikasi pendidikan S1. Standar sarana prasarana sudah baik. 
Kedua adalah aspek pembelajaran, materi, penilaian dan pengamatan belum dilakukan secara utuh dan terintegrasi dari pagi sampai sore. Ketiga, capaian perkembangan anak sulit ditemukan dilapangan karena seluruh lembaga PAUD tidak memiliki data rekapan pencapaian perkembangan anak dan deskripsi penilaian. Keempat, materi pembelajaran terbatas pada kegiatan inti dan kegiatan setelah pembelajaran lebih banyak pada pengasuhan, sehingga dari pengembangan model PAUD Fullday diperlukan kegiatan pembelajaran utuh dan berkesinambungan dari pagi sampai sore.

Saran.

Berdasarkan simpulan dari hasil penelitan dapat diberikan beberapa saran sebagai berikut: (1) perlu dibuatkan model pembelajaran utuh terintegrasi dan holistic dari pagi sampai sore; (2) perlu dibuatkan format silabi, RKH dan format penilaian sebagai kelengkapan dari model pembelajaran fullday yang integratif dan holistic; (3) perlu dibuat design kegiatan pada sore hari sehingga tidak hanya fokus pada pengasuhan tetapi ada proses stimulasi yang terencana dan teramati dengan baik; (4) perlu dibuat format untuk merekap data-data perkembangan siswa agar sekolah memiliki data yang dapat digunakan untuk pengembangan pembelajaran di sekolah

\section{Daftar Pustaka}

Dewantara, K.H. (1962): Pendidikan Bagian I. Yogyakarta: Taman Siswa:.
Faturochman. (2001). Revitalisasi peran keluarga. Buletin Psikologi, tabun IX No 2, Desember 2001, 39-47.

Hurlock, E. B,. (1999). Perkembangan Anak. Jakarta. Erlangga.

Hoffman, L. W. The effects of the mother's employment on the family and the child.

http://parenthood.library.wisc.edu/ Hoffman/Hoffman.html. Di unduh pada tanggal 15 April 2013.

Hildebrand, C. Effect all-day, half day kindergarten programming on reading, Writing, Math and classroom sosial behaviours. University of Nebraska. Diakses dari http:// nationalforum.com/Electroni c\%20Journal $\% 20$ Volumes/Hildebran d, $\% 20$ Charlene $\% 20$ Effects $\% 20$ of $\% 2$ 0All-day $\% 20$ and $\% 20$ Halfday $\% 20$ Kindergarten $\% 20$ Programmi ng.pdf

National Center for Education Statistik. (NCES). (2014). Half day and fullday in The United States.

Plucker, J., et. all. (2004) : The effect of fullday versus halfday Kindergarten. Indiana.

Sudjana, D. (2006). Evaluasi Program pendidikan Luar Sekolah Untuk pendidikan Non Formal dan Pengembangan Sumber Daya Manusia. Bandung: PT Remaja Rosda Karya.

Tjaja, R.P. Naskah No 20 tahun (2004): Perempuan bekerja dan implikasi sosial. Bappenas Pusat Jakarta.

UNESCO (2005) : Laporan tahunan PAUD di Indonesia. 